\title{
FILM INDUSTRY TRENDS IN SULAWESI: AN ECONOMY-BASED CULTURE AS A NEW ECONOMIC FORCE
}

\author{
Abd. Rahman \\ Airlangga University
}

\begin{abstract}
Indonesia's wealth potential is very large and wide, one of which is cultural diversity. Surely this is likely to encourage the competitiveness of the Indonesian nation in the future by prioritizing creativity and innovation in national development to optimize the potential wealth of its possessions. In this research, the researcher wants to expose the trend of film industry in Sulawesi which most of the film take local title close to daily, or local culture. Such as a movie uangpanai' prove that local films still get a warm place in the people of Indonesia. This film became the first regional film that can penetrate Box Office Indonesia. The film gets a new stage, Dozens of production houses $(\mathrm{PH})$, acting classes, and a number of movie titles keep popping up so that opens up many job opportunities. So that later Indonesia will no longer rely on exports of raw materials, but will also be able to export high value-added products. Creativity and innovation will also make the local cultural heritage and wisdom contribute greatly not only to the national economy but also to improving the image of the Indonesian nation in the eyes of the international world. The two main approaches used by this journal in the development of the national creative economy, the national collaborative approach, namely the collaboration between industrial sectors, universities, government, business actors, and the creative community; As well as strategic focus approach, that is, the government must be bold in determining the focus of creative industry development in terms of determining the focus of industry sector and creativity-based areas that will be developed.
\end{abstract}

Keywords: Industry, Economy, Culture

\section{Introduction}

The distribution of the film and the show became a business so lucrative that can change the production studios into film companies. These companies then gave birth to the ' studio system ' where film production adopted the factory system working takes a lot of human resources to produce a product in the form of entertainment. Development of an indirect film industry turns out to have been contributing to the economy and creating jobs. In 2010 a study carried out by Oxford Economics and research consultants have noted the contribution of US $\$ 845,1$ Million and more than 191,000 jobs and tax revenue of US $\$ 86,5$ Million that can be given film industry.

The film is currently developing as a new culture that is widespread among the people they would see, observe, and understand what the content of culture and values brought in the film. The themes of films in Indonesia, most created ranges to the stories of romance, horror, consumerist life and violence. Can not be denied that the films in everyday life often fill the screen-screen television or cinema in Indonesia. But some of the movies that get the attention of the world in particular occasionally thus films that uplift the social conflicts, politics and culture. (T. Unruly, 2009, p. 3)

Cinema of Indonesia has enough material to serve as the film's content, such as movies by lifting the social issues that are the social conditions of an area. In this respect in the year 2016 Panai Money movie ' that lifts the story about local cultural wedding traditions in Sulawesi namely Bugis-Makassar and Sinamot film that raised about Batak tradition, LaskarPelangi cultural backgrounds Malay-Belitong which has a simple personality and bershaja in every life. And most recently in the year 2017 is the killer Marlina in four Rounds, the film takes the 
cultural background of Sumba, East Nusa Tenggara, about the struggles of a woman in the face of disaster, the brave against the infiltration.

Fil-film about the culture proves that the local culture when it is packed with good can be very beautiful, attractive and able to give you an idea of the local community about local culture. As the success of the film ÚangPanai ' proven record boasts with a total of 526 thousand spectators, the film became the highest grossing film of the area in 2016, which could penetrate the Box Office Indonesia. Movie Money local movie panai'a is from Sulawesi was the inspiration of the film makers to produce movies with the theme local wisdom. Interest of the community saw Panai Money ' turns out to be proof that film production areas can be frowned upon and have a quality that is comparable to national films. With the film's production notes and have a strong story (IBOMA 2017).

This is the first study that comprehensively measures the economic impact of direct, indirect and posed by the film and television industry of Indonesia. This study also reveals how the film and television industry affects a wide range of service industries and a significant employment in other sectors. In the history of the development of the mainstream film industry in Indonesia, Indonesia experienced the films much progress very rapidly. Current homeland film is already able to demonstrate its success to showing films that are closer to the culture of the nation of Indonesia. It is attested by the emergence of quality films under her creativity Indonesia's film industry in the 1990s due to the nation's identity crisis in Rapture the themes the film in production at the time (Ardiyono, Yoppy, 2015, p. 9).

There are 14 sub sector of the creative industry, namely advertising, architecture, art, crafts, design, fashion, photography, film and video, interactive games, music; art shows; danpercetakan publishing; computer services and software; tv and radio; as well as research and development. The growth of the creative industry year 20062009 exports recorded 2, 9 percent. With designated the Ministry of trade, Ministry of industry, and the Ministry of Tourism for the creative industry, among the perpetrators of the industry expect much (Dina Mellita, 2014, p. 5).

After scrutiny then needs HUMAN RESOURCES especially in the movie industry that fits their field of competence is very urgent. People themselves see that this is an industry that desperately needs a reliable HR challenges so that it is able to turn on a television program content in the middle of the entertainment industry's competition is very tight. The Government has set the development of the creative economy as part of the agenda of national priorities, as well as forming the BEKRAF to control the creative economic development. To realize the creative economy as Indonesia's new economic power, creative economic development in Indonesia in the long term is directed not only to menumbuh develop creative industries but furthermore able to hone creativity and innovation in every sector of society and life (Handriyotopo, 2014, p. 3).

The phenomenon of shifting a flow of film industry, especially the film Indonesia from time to time by doing a deeper examination of the associated comparison between two different industries and a shift in the behaviour of the perpetrators of the industry itself in it's each industry has been in masukinya. The main impact upon commodification applied today is the loss of esensialisme on the inside. The film, both in terms of production, to consumption of movies. That action over media content could be made, however should the making of idealism as well as consumption of the content of the film must still be unlimited autonomy possessed by a product of the film, the filmmakers themselves as creators and audience/consumer as a film connoisseur - at the same time, through the film. The term rekomodifikasi is inside the administrative culture of consumption as the era of postmodernism, the market mechanism is considered to have failed to resist the power of the audience/consumer (Claus Offe, Contradictions of the welfare state, 1984). 


\section{Method and Purpose}

This research uses descriptive qualitative approach, using quantitative data. Aims to describe and disclose an issue regarding the form of commodification in the process of cultural development program serving. According To TheMoh. Nazir (1998) a descriptive research is a method in researching a group of humans, an object, a set of conditions, a system of thought or a current events class. The purpose of this descriptive study was to create a description, a picture or painting in a systematic, factual and accurate regarding the facts, properties and relationships between phenomena examined. Descriptive research using data collection techniques of observation and in-depth interviews. By looking at successful, failed, or is satisfied from an event. To achieve this study researchers determine precisely the type of information or data that is needed, so that from here researchers makes pertanyaam-questions with the corresponding response categories. The question for the purpose of gathering information from the main categories namely, opinions, beliefs, and perceptions.

The goal in this study was inigin see the development of the film industry which is in Sulawesi. And want to know the local culture utilization in Sulawesi against content contained on some movies that are in Sulawesi.

\section{Research Results}

The development of the film industry Indonesia lately, encouraging. Attendance at 2016 increases very significantly. Catalog Film Indonesia launched film industry development center of the Ministry of education and culture has recently been mentioned that, as of October 2016, as many as 103 films screened in theaters suck 28.4 million viewers, up than on previous year (2015), 15.4 million. In addition to attendance, other evidence mentioned that the development of the film industry is no longer Jakartasentris. Example, Siti, independent film work of Eddie Cahyoo who was chosen as best film Festival Film Indonesia and Indonesia 2015 Film Appreciation. In addition, the films YosepAnggiNoen, filmmakers from Yogyakarta, be subscribed international film festivals. Even the film, entitled Rest words, finally premiered in theaters. Creative industries are expected to support the digitization of economy in Indonesia, so ideally the Government makes the creative industries as a priority industry.

Makassar in recent years also produced a long story in the best-selling local movie theatre with raked 521,028 audience. Mass communication media that very high levels of devotees is the film, such as the data source of the Cinema 21, PPFI, Blitz:

- o Year 2008: Rp 13,000/audience

- o Year 2009: USD 14,000/audience

- o Year 2010: Rp 15,000/audience

- o the year 2012: Rp 22,000/audience

- o Year 2013: IDR 30,000/audience

- o the year 2015: IDR 35,000 spectators

Based on the above data shows that every year the movie audience is growing. It means that the film be a form of mass communication media that are very sought after by today's society. The selection of the medium used to disseminate the ideas of culture is very important to support the effectiveness of the message. The choice should be dropped on media most preferred by most local masayarakat (Kayam, 1982, p. 23)

And more and more movies that began to appear in other areas, such as Belitung, Batam, Pontianak, and Kutai, which circulates in the cinema. Is certainly the important question of relations between the two, how culture can develop in line with the application of the creative economy. The more pentingya the role of creative economy in the national economy as well as the characteristics of Indonesia that is famous for the diversity of sosio- 
budaya scattered in all corners of the archipelago surely can be a source of inspiration that never dry in did the development of creative industries. The diversity that characterized also by the local wisdom of local communities in maintaining sustainability of culture has been going on between generations. Daniel Pink in his book, explaining that the creative sector that developed in developed countries hard emulated by other countries because more emphasis to specific ability that involves creativity, skill and talent (The Whole New Mind, 2006)

The films production of Makassar in the ranks of top-tier national film industry 1940s 70-80. Some of the works produced a booming City that time of which follows a Seven Wells, Sanrego, and Twilight on the beach Losari. In the heyday of film industryappeared Makassar one figure of Makassar artists with "scents smell" named Rahman Arge. Enter the era of the years 90, the film world Makassar became sluggish in line with lunglainya the national film industry. Most of the perpetrators of the perfilm the 90s switched to glass display (TV TVRI, 1990).

After the production of the film the man from Cape Bira release year 1992, hardly heard from again echoes of film production from Makassar. The film world of Makassar "suspended", grim and helpless. Beginning in 2000, the production of the film in the Makassar back popping up but most is done in the format of Indie. The release was only fulfilling a Youtube Channel. The year 2003, a local television station that is the dawn of TV, in cooperation with IchwanPersada, trying to excite the local film industry peers with the television program, "Sinemania", but does not affect samasekali. Nearly a decade until it runs a condition when a work of widescreen movies in 2010 titledAliguka, begin to open space. Although it has not yet been calculated, commercial film "idealistic" hosts the Dewarti Arman tilled with minimal costs is beginning to answer the dominance of creative space for a row of national film production that has been synonymous with Jakarta, Bandung or Java and surrounding areas. The film world made the movie jerks, there emerges from Makassar. Aliguka film is packed thick with Makassar nuanced typical local style. The film lasts about 70 minutes of this recording a variety of paradoxical reality of the lives of the citizens, ranging from high-rise slums are suffocating, the struggle of the poor of the city night life to the prostitutes in this city.

Aliguka is considered as the beginning of the revival of the world per-filman Makassar that rusty so long. Though not very popular, echoes of the film Aliguka was able to give the film an iconic influence on Indonesia, RiriRiza to return to his hometown. He then builds a community of Rumata ' and open up opportunities for supporting the rise of local film production in Makassar. Since then, the production of quality films began to appear. Many film makers out of the nest. Note the achievements of local film production is an amazing start ditoreh when a young director of Makassar, Andrew Parinussa won an international film festival in Japan in 2013. Garapannya short film entitled Does, success is getting rid of 11,657 film works from around the world and has the right to the award-winning "first prize". Makassar entered in the 6 best film world. A year of success in Japan, following the work of Cinematographers young short film other, Makassar Aditya Ahmad titled "new shoes" won the international award Special Mention for the best short Film category Generation KPlus in The Berlinale, a party to the International Film Festival-64 which was held in Berlin, Germany, February 16, 2014.

The year 2014 is the phase where the Makassar film production had already begun rediscovered his breath. Some film production from makers of Makassar which received national awards and appreciation. During the transition, a film-production genre fiction drama of a group Art2tonic with the title "Bombe" finally managed to break through the commercial film industry by working with the national cinema network, XXI. Despite the political nuance, the Bombe tremendous acclaim from society of South Sulawesi. Art2tonic the digawangi Director named Rere is a success removing film industry long thirst in Makassar and make local film production host in her own country. Art2tonic is recorded as pembesut local film the most fertile in Eastern Indonesia. A row of film production, among others, Bombe, Bombe2, Dumba-dumba, Sumiati and Lastly, Love the taste of chocolate, everything got a tremendous response and able to penetrate the market to the Java island amid the fierce Western film and the national film. 
The year 2016, a local film company Makassar, Makkita Cinema productions, also succeeded in creating new breakthrough with crime movie called "money Panai". Film-comedy genre that brings the theme of the social life of the community in South Sulawesi recorded a new history in the commercial film industry in Makassar. In cooperation with a network of XXI, 21 cities in Indonesia showed the film in which most of the movie theater had to open two screens due to the number of viewers who quickly become unmanageable. Movie Money Panaik that in produseri by Emery Nuryan this involves the singer KatonBagaskara as popular artist of his supporters. Since it was released August 25, 2016, the movie is a success straddling some film.

The film industry that started to squirm and Makassar successfully mastered its market dikandang alone, has now opened the eyes of the perpetrators of the creative industries in Indonesia that the industry per-filman Makassar was up from a long sleep. When the road and its spatial is already open, the world's per-filman Indonesia preparing to enjoy the back color of the creativity of film makers invasion of Makassar which in general have distinctive characters with their local power. The film industry in the city of Makassar became increasingly conditioned passion. Many film communities popping up, up to being able to trigger the creativity of young people of Makassar in the film industry.

Therefore, it is very plausible if pentolan Ar2toic Band vocalist at once is so eager to continue creating works of film that raised local culture and wisdom in Makassar of South Sulawesi or in General. Director and screenwriter said, stretching the film industry while is indeed being in Makassar. Production house (PH): as finicia productions, Mattuju Indonesia, and pparamedia film, Makkita Cinema, acting classes, and a number of the film's title remained, with the advent of home production brings influence to the economy in Makassar namely positive impact that will effect on social life, business climate, economic improvement, and also affects the image of a region. Film industry has proven to have a significant contribution in boosting growth are in the other sectors. (Kompas.com, 2016)

The film industry is expected to boost the growth of the film industry can thus also enhance the contribution of the film industry's response to the national economy. Makassar as one of the major cities in Indonesia also became a funnel for presenting the films close to Bugis society-life joints Makassar itself. That has the potential to sell high-value at the moment is the film or film comedy genre film that raised local cultures inspiring. Young people in each region ought to be appreciated because it can be an inspiring tale of uplift of art worth watchable. Menumbuhkembangkan creative economy cannot be separated from the local culture. Culture should be a base for development.

In the local culture there is called the wisdom of local (local geniuses) who becomes a meaningful values, has translated into a physical form in the form of local creative products. RevrisondBaswir of GadjahMada University economist, said that the creative economy can not be seen in the context of the economy, but also the cultural dimension. Creative ideas that emerged was a product of the culture. Therefore, the strategy for culture strongly determine the direction of development of creative economy. Each region/territory generally has the potential products that can be raised and developed. The uniqueness or the specificity of local produce that is what must be the bottom line then added an element of creativity with the touch technology. Please just one region and other regions have similar products, but each area must maintain his trademark.

According to Arman, For Film required given the Makassar is one of the local film industry was considered by some observers a movie outside (Makassar) potentially enough, let alone post movie success New Shoes at the Berlin Film Festival in 2014. Makassar through For Film is expected to be able to make the city a more advanced perfilmannya also follow the progress of the film industry in the island of Java, such as Yogyakarta or Purbalingga. Here are a few films that tells the story of South Sulawesi to ever broadcast in theaters homeland. 
- UangPanai' ( Dowry)

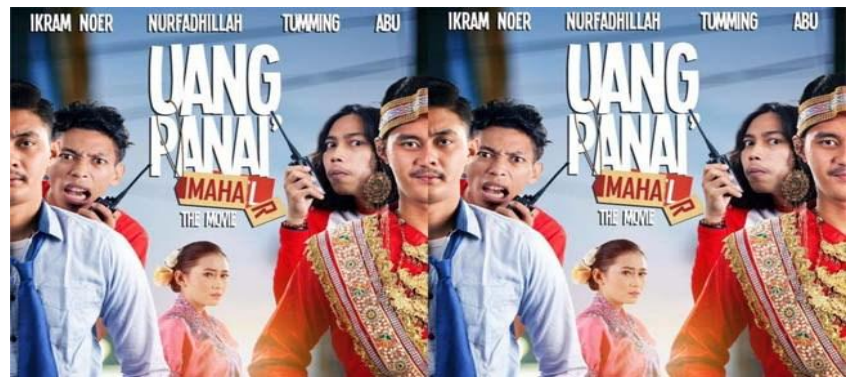

The film raised local people's life stories, this film became the Makassar first able to penetrate regional Box Office Indonesia. At least more than 400,000 pairs of eyes have already watched the movie that this comedydrama genre. Though it is only present in 20 cities, regional films of South Sulawesi is able to capture more viewers than any other national films. This is because the story of the area and audience factors that have a strong bond, so that those who missed the typical good comic Makassar can be alleviated after watching this movie.

- 2. Bombe'

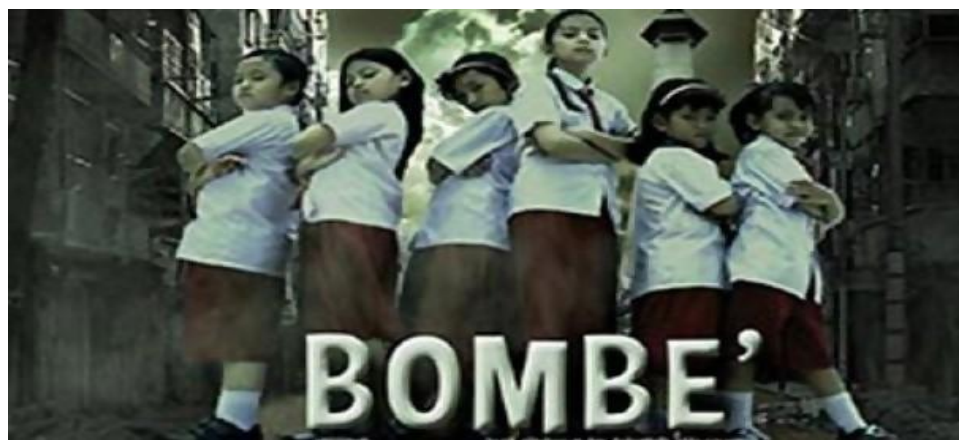

Film Bombe ' present on the cinema screen in the year 2014. Story about the city of Makassar which suddenly silent without any activity, it was able to lift the enthusiast community. A typical dialect of Makassar city and the presence of acting little kids that became a major player in the film became the attraction of the film. Mr. IlhamArifSirajudin Makassar mayor who served at that time, also took a role in a film that lasts 100 minutes. He was present as a gatekeeper that would explain why the Makassar city suddenly silent without any activity as usual.

- 3. Sumiati

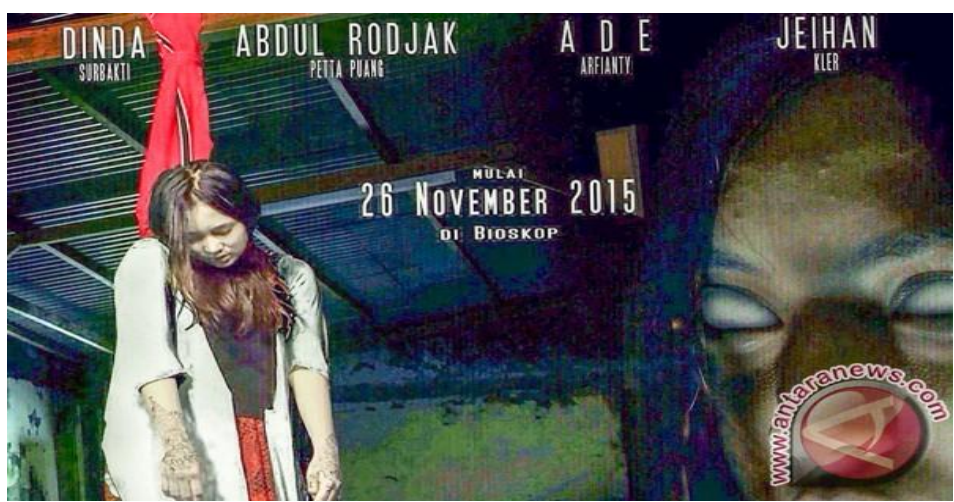


Attendance at movie theaters in the past 2015, Sumiati became one of horror films that take place in South Sulawesi. To the community in South Sulawesi alone, the legend of Sumiati is very diverse. Each location, legends about how the death will be different. But his character remains Sumiati. The movie is told about the frustrating sumiati died after being raped by people who are not responsible. Take a shortcut, he ended up hanging himself. As the embodiment of the pain in his heart, he'll do his revenge.

The growth of the film industry in Makassar in recent years certainly cannot be separated from the learning interest of young children there. For Riri, young kids in Makassar have a very powerful learning desires. They pioneered the film industry long enough, starting from learning, pursue tastes and keep the quality of the production. The success of the child-made films of Makassar before undertook to open the door to new in the world of cinema for children of Makassar to another. The achievement of local movie audiences as much as 600 thousand people, indicate if the film industry in Makassar city ahead of other cities.

The film is also seen as a medium of dissemination and publication culture a powerful and persuasive. The proof is the event events festival film sort of Jiffest (Jakarta International Film Festival), the French Film Festival, the European Film Week, and tech is an annual routine in organized in Indonesia. The films are presented in the various races of the festival of yesteryear has acted as an Ambassador of their own culture, to be introduced to the community who have a culture which is certainly different to the film from where came from.

\section{Discussion}

The theme of the story films in Indonesia tends to follow or it could be said to be seasonal. That is because the film in Indonesia was strongly influenced by the lifestyle that is the result of invasion of cultures outside the culture of Indonesia. The invasion resulted in the bergesernya of moral and cultural values in the younger generation. This phenomenon is evident in the style of life that the longer the more abandoned native culture. Culture is the identity and wealth that is typical of a country that should be conserved. Therefore, the themes of films in Indonesia should put more emphasis on original cultures Indonesia as an embodiment of cultural preservation. With such a culture can become commodity products from the content of the film. John Howkins defines economics as a creative economy that makes the creativity, culture, cultural heritage, and the environment as the object of the future. Creative economy concept was later developed by the Economist (Richard Florida, 2001).

Since the beginning of the national cinema was built, Mr. film Indonesia, Usmar Ismail film inserted in order to fight and is seen as a work of art. The film is indeed a work of art, but as a form of artistry, the film includes two media utam i.e. see and hear the complex combines various forms of art that disublimasikan becomes a form of art products where music, painting, theatre, graphics, taxi, animation, photography, poetry, and other forms of art which can contains "(Kristanto in widagdo, 2011:82).

In The book The Rise of the Creative Class and the Cities and the Creative Class, Florida about creative industries in the community. According to him, man is essentially creative, whether he is a worker at the factory of glasses or a teenage gang who were making music senggol hip-hop. But the difference is on its status, because there are individuals who are specifically being in the areas of creative and get economic benefit directly from the activity of the group. Countries, territories, or areas that are able to create innovative new products the fastest will be the winner of the competition in the era of global economy. Starting from the United Kingdom's creative economy now, many adopted developing countries including Indonesia. With the composition of the population of the young age of about 43 percent, or about 103 million people, Indonesia has a considerable human resource for the success of creative economic development. Not to mention other potential (Moelyono, 2010).

The existence of the film industry sector in the country reflects the social and cultural conditions of the nation. Because each country has a different cultural background, then any dynamism and growth of the film industry in 
each country. Through the actual film we learn about culture. Be it the culture of the society in which we live in it, or even a culture completely alien for us 2 . And we become knowing that this culture and the culture of this was so, primarily through a movie. The film is also seen as a medium of dissemination and publication culture a powerful and persuasive. The proof is the event events festival film sort of Jiffest (Jakarta International Film Festival), the French Film Festival, the European Film Week, and tech is a routine annual held in Indonesia. Festival Film Indonesia in recent years began to be switched on again after a stalled long enough.

The films are presented in various festivals of yesteryear has acted as an Ambassador of their own culture, to be introduced to the community who have a culture which is certainly different from the culture that was made into the film. Ambassador bureaucratic. The elements and the value of this culture that often escapes dish television. Television media can not or rather do not feel the need to present cultural values as tersajikan through the medium of film. The film used as a reflection to the glassy or to see how a culture of working or living in a community. The film not only mengkontruksikan a certain cultural values in its own right, but also on how the values of yesteryear is produced and how it is consumed by the people who watched the film. So there is such a process of exchange of cultural codes in Action Watch the film.

Commodification occurs due to the result of the development of a cultural industry. Where the production of cultural objects (music and film) in pre-industrial times is produced autonomously/pure, there is no interference with any industry the market system in the production process. But in an era of globalization with the system capitalism brings out the cultural explosion of the real aspect of life, so that gave rise to the needs of the masses. In this case, an industry has been producing a wide range of cultural artifacts that seem to have become the need of the masses and become a deciding factor in the production process, so that the cultural objects that were previously filled with high values, authentic ( Authenticity), and the truth (truth), by industry cultural massproduced commodity full calculation of profit (profit). As an example of a form of commodification is happening in film industry is the local culture in Makassar that are packaged in an attractive display to be consumed in mass through the film. By taking local stories as conten of film making as a cultural product that has an extremely high rate in the film industry. Film critic France André Berzin, who argue that its greatest strength lies in its ability thus cinema presents back reality as original (Adorno and Horkheimer, 1979, p. 206).

In teoritik, commodification explains how capitalist in keeping an objective to accumulate capital or the effort to value through the transformation of values in order to exchange rates. Commodification has changed the object, the quality and the signs of becoming a commodity in which the commodity is the items that can be sold on the market. Commodification is often followed by a distinguishing cultural commodities manipulation and superficiality of authentic communities (Marx, 1977). Critical perspectives in the political economy of the media, the container is the occurrence of the practice of commodification is done in the mass media, in which occur between the economic interests of attraction (owners of capital) and political (power game) is the result of media products construction tailored to the dynamics of an ongoing economic and structural-sturktur in institutions supporting the berputarnya wheel of media institutions, where economic interests and politics usually comes from the owner of the media and a market-driven system understand capitalism (Golding and Murdock 1992:18).

Commodification practices according to Mosco (2009:134) on television media marked with which he changed the content/media content into a commodity for profit. One strategy in the achievement is producing television programs to suit the tastes of the market so as to raise the rating. The use of ratings as benchmarks in view of the success of a program. Rating tool to assess content (text/media products) are eligible for sale. Eligibility is characterized by how much advertisers are able to be drawn in any particular program serving. In addition, the rating also be data in the mengkomodifikasi audience. The data summarized in audience rating into a foothold for the advertisers to market their products in certain impressions program or not. As the development of creative industries in various countries, being able to demonstrate empirically the driving sector for the growth of other economic sectors, including industry-based culture (Mosco, 2009, 134). 


\section{Conclusion}

The economic crisis that still overshadow Indonesia, proved that the efforts of economic development still needs to continue to be improved, in order to have a tough life durability. Therefore, it is high time it takes a real program to create a significant movement, expected later will give an impact on improving the quality of the economic development of Indonesia. Culture-based industry is the industry that serves as a shield the identity of a nation. Through the development of the industry is expected to be formed within the "development of the character of the nation" who appreciate culture for later applied in day-to-day life and are introduced to the world at the same time able to improve growth economy. For example, introducing and preserving culture through film content from existing local culture in Indonesia.

The existence of the film industry in major cities other than the capital of Indonesia gave a positive social impact on the economy, creative film industry will become the backbone of Indonesia's economy forward. The presence of the local film industry opens up great opportunities for people who have expertise in the field of cinema, such as acting, production, talent technician, all that can be tersalurkan with the film industry, people don't have to come again to the capital Jakarta to attend the casting actor, or as the crew of an industry production house.

With such strong economic movement in every cities in Indonesia will help the movement of the economy nationally. The creative economy is expected based on local wisdom can push Indonesia toward the development of more advanced and has a high competitiveness. In addition, based on local wisdom, then the preservation of culture remain awake and able to prevent the existence of exploitation of culture itself, and is expected to realize the lasting power are manifested through the view of life, knowledge, and various strategies the life form of the activity carried out by the local community to address various problems in the fulfilment of his life while maintaining the culture.

\section{References}

Adorno and Horkheimer (1979) in his The Culture Industry of the U.S. Mass Enlightenment Deception

Ardiyono, Yoppy. (2015). The development of Indie Filmmakers Motifs in the face of the industry

The Movie Mainstream. Journal article. Volume VII.

Anggraini, Nenny. (2008). "creative industries", Economic Journal Volume XIII No. 3

ANDA, r., h. Bakhshi, w. Hutton, a. O'Keeffe, p. Schneider (2007). Staying Ahead: The

Economic performance of the UK's Creative Industries,

The Work Foundation, London

Mokhamad Anwar,, et al. (2007). identification of the industrial sector and its role in increasing

The Original Income Garut Region. pustaka.unpad.ac.id/wp-

content/uploads/2011/08/Identifikasi_Sektor_Industri.

IndraBUDiIrwanto (1999). The film, ideology and military: military hegemony in the cinema of Indonesia Yogyakarta: Media Name.

BurhanBungins, m. h. (2007). Qualitative Research: Communication, Economics, Public Policy, and social sciences, Singapore: KencanaPrenama Media Group.

Daniel Pink, (2006), in his book, "The Whole New Mind"

Insan. (2014). Opportunities and challenges the industry's Creative People and reliable Printer In The World Of Television. Journal Article. Volume 6.

Gita SukmonoFilosa. (2013). Political economy of the Media. Yogyakarta: Beltway Media, Article.

Regulation Number 72, year (2015) about changes to the presidential regulation Number 6 years 
the Agency's Creative Economy Of 2015

Mellita, Dina Erlansyah, Natalie. (2014). Mapping creative industries in enhancing

The Economic Growth Of The Urban Area In The City Of Palembang. Jounal Article.

M. BayuWidagdo. (2011). The role of Government In policy making Film Indonesia

At the time of the new order and reform. Semarang: University Of Diponegoro.

Marirossi, Danis. (2005). McQuail's Mass Communication Theory. London: SAGE Publication

Ltd.

Mosco, Vincent. (1998). The Political Economy Of Communication: Rethinking and Renewal.

London: SAGE Publication Ltd., Offe

Mosco, (2009) the practices of commodification

Academics:BRMBambangIrawan was a lecturer at the Faculty of Economics of the UNS and also the leading Solo artists.

Practitioner: SlametRahardjoDjarot, a humanist, but he is also better known as the famous actor and Director who already have a lot of work.

Government representatives:SaptaNirwandar, the Deputy Minister of tourism and Creative economy of Indonesia.

http://dppm.uii.ac.id/dokumen/dikti/files/DPPM-UII_07._52-

66_Pengembangan_Ekonomi_Kreatif_Sebagai_Penggerak_Industri_Pariwisata.pdf

http://repository.usu.ac.id/bitstream/123456789/31611/4/Chapter\%20II.pdf

Monday, 07 September 2015-20:03 ,https://ekon.go.id/berita/view/ekonomi-berbasis-kreativitas.1659.html 